See discussions, stats, and author profiles for this publication at: https://www.researchgate.net/publication/333132759

\title{
Breaking the Grenville-Sveconorwegian link in Rodinia reconstructions
}

Article · May 2019

CITATIONS

0

5 authors, including:

Morgan Ganerød

Norges geologiske undersøkelse

57 PUBLICATIONS 677 CITATIONS

SEE PROFILE

Some of the authors of this publication are also working on these related projects:

Geochronology of Jan Mayen View project

Flood Basalts and Volcanic Rifted Margins View project
READ

1 
DR TROND SLAGSTAD (Orcid ID : 0000-0002-8059-2426)

Article type : Paper

Received date: 20-Mar-2019

Revised version received date: $23-\mathrm{Apr}-2019$

Accepted date: 26-Apr-2019

Correspondence details:

Dr Trond Slagstad

Tel: +4773904229

Fax: +4773921620

E-mail: trond.slagstad@ngu.no

Data Availability Statement: Data sharing is not applicable to this article as no new data were created in this study.

\section{Breaking the Grenville-Sveconorwegian link in Rodinia reconstructions}

Trond Slagstad ${ }^{1}$, Evgeniy Kulakov ${ }^{2}$, Christopher L. Kirkland ${ }^{3}$, Nick M.W. Roberts ${ }^{4}$ \& Morgan Ganerø ${ }^{1}$

${ }^{1}$ Geological Survey of Norway, PO Box 6315 Sluppen, 7491 Trondheim, Norway.

${ }^{2}$ Centre for Earth Evolution and Dynamics, University of Oslo, PO Box 1028 Blindern, 0316 Oslo,

Norway.

${ }^{3}$ Centre for Exploration Targeting-Curtin Node, School of Earth and Planetary Sciences, Curtin

University, Perth, WA 6102, Australia.

${ }^{4}$ NERC Isotope Geosciences Laboratory, British Geological Survey, Nottingham, NG12 5GG, UK.

This article has been accepted for publication and undergone full peer review but has not been through the copyediting, typesetting, pagination and proofreading process, which may lead to differences between this version and the Version of Record. Please cite this article as doi: 10.1111/ter.12406

This article is protected by copyright. All rights reserved. 
Keywords: Valhalla, Sveconorwegian, Grenville, North Atlantic, Rodinia, Neoproterozoic

\section{Abstract}

The Grenville, Sveconorwegian, and Sunsas orogens are typically inferred to reflect collision between Laurentia, Baltica, and Amazonia at ca. $1.0 \mathrm{Ga}$, forming a central portion of the Rodinia supercontinent. This triple-junction configuration is often nearly identical in otherwise diverse Rodinia reconstructions. However, available geological data suggest that although the Grenville and Sveconorwegian provinces shared a similar tectonic evolution from pre-1.8 to ca. $1.5 \mathrm{Ga}$, they record distinctly different tectonic histories leading up to, during, and possibly following GrenvilleSveconorwegian orogenesis. Moreover, paleomagnetic data suggest the two continents were separated at peak orogenesis, further invalidating any direct correlation. A number of possible interpretations are permissible with available geological and paleomagnetic data, of which a 'classic' triple-junction configuration appears least likely. In contrast to the commonly inferred intertwined Proterozoic evolution of Baltica and Laurentia, the possibility remains that they were unrelated for a billion years between 1.5 and $0.45 \mathrm{Ga}$.

\section{Introduction}

Periodic aggregation and dispersal of continents has likely exerted a controlling influence on the formation and preservation of crust, mantle dynamics and the evolution and diversification of life on our planet (Nance, et al., 2014). However, apart from the most recent supercontinent - Pangea supercontinent reconstructions are fraught with uncertainty, to the point that their very existence has been questioned (e.g., Evans, 2013). In the absence of faunal evidence, reconstructions are generally based on available paleomagnetic data and correlation of orogenic and/or magmatic/metamorphic events on different continents. Several reconstructions exist for the late

This article is protected by copyright. All rights reserved. 
Mesoproterozoic Rodinia supercontinent (Fig. 1). Although reconstructions vary widely, they all imply that Laurentia and Baltica remained in close proximity before and during Rodinia assembly. This inference of proximity largely stems from correlation of the late Meso-/early Neoproterozoic Grenville and Sveconorwegian orogens (Gower, et al., 1990), and sparse paleomagnetic data (Li, et al., 2008). In this contribution, we review evidence that the Sveconorwegian Province is highly unlikely to be a correlative of the Grenville Province in Laurentia, consider how paleomagnetic data are consistent with the two orogens being widely separated at the peak of GrenvilleSveconorwegian orogenic activity, and discuss how evidence from late Meso- through Neoproterozoic allochthonous units around the North Atlantic region, albeit circumstantial at present, may provide constraints on Baltica-Laurentia contiguity.

\section{Paleo- through Mesoproterozoic tectonic evolution of the SE}

\section{Laurentian and SW Baltican margins}

Laurentia and Baltica are generally interpreted to have shared a common tectonic evolution starting at ca. $1.85 \mathrm{Ga}$, characterized by crustal growth and reworking along their SE and SW margins, respectively (Fig. 2A; Condie, 2013, Karlstrom, et al., 2001, Roberts and Slagstad, 2015). Most models of Rodinia assembly suggest that this coevolution ceased when the two margins collided with a third continent (Amazonia) to form the Rodinia-interior Grenville-Sveconorwegian-Sunsas orogenic belt (e.g., Karlstrom, Åhäll, Harlan, Williams, McLelland and Geissman, 2001, Li, Bogdanova, Collins, Davidson, De Waele, Ernst, Fitzsimons, Fuck, Gladkochub, Jacobs, Karlstrom, Lu, Natapov, Pease, Pisarevsky, Thrane and Vernikovsky, 2008). However, although there are numerous similarities between the two margins until ca. $1.5 \mathrm{Ga}$, the succeeding evolution is less clear. The SE Laurentian margin was characterized by formation of widespread, Mesoproterozoic arc and back-arc systems that were assembled through a series of ca. 1.25-1.12 Ga Elzevirian and Shawinigan accretionary

This article is protected by copyright. All rights reserved. 
events, prior to emplacement onto Laurentia during the Grenvillian orogeny (Carr, et al., 2000, Culshaw, et al., 2013). Ensuing Grenvillian orogenesis involved northwestward thrusting of these assemblages as ductile nappes at high-metamorphic grades, probably with the development of a wide orogenic plateau, and is generally inferred to represent continent-continent collision with Amazonia starting at ca. 1.1 Ga (Culshaw, et al., 1997, Rivers, 2012, Rivers, 2015). Late-orogenic extension of ductile crust may have been underway by $1050 \mathrm{Ma}$, and certainly by $1020 \mathrm{Ma}$, juxtaposing upper-crustal rocks of the orogenic lid with deeper, more ductile rocks (Rivers, 2012). The late-orogenic extension was followed by a late compressional event, the Rigolet phase, at ca. 1005-980 Ma, close to the orogenic foreland.

In contrast, the SW Baltican margin appears to have been mainly in extension until ca. $1.10 \mathrm{Ga}$, as evidenced by widespread continental bimodal magmatism and sedimentation (Bingen, et al., 2002, Brewer, et al., 2004, Spencer, et al., 2014). Although this extension may have taken place behind an active continental margin, no outboard arc/back-arc terranes were accreted onto Baltica during Sveconorwegian orogenesis. Sveconorwegian orogenesis between ca. 1140 and $920 \mathrm{Ma}$ is characterized by distinct tectonometamorphic events in different parts of the orogen at different times (Bingen, et al., 2008, Bingen and Viola, 2018, Möller, et al., 2015, Slagstad, et al., 2018, Slagstad, et al., 2017). Unlike the Grenville, the tectonic evolution of the western part of the Sveconorwegian orogen was distinctly different to that of its eastern part, close to the foreland. The latter region was characterized by a high-pressure metamorphic event at ca. 990-970 Ma, and has been a main argument for invoking collisional processes correlative with the Rigolet phase in the Grenville (Möller, et al., 2013). This interpretation, however, neglects the western and central parts of the orogen that were characterized by widespread magmatism and high- to ultrahightemperature metamorphism - rather different from that observed in the Grenville and more compatible with active-margin processes (Blereau, et al., 2017, Bybee, et al., 2014, Coint, et al., 2015, Slagstad, et al., 2013). Slagstad et al. $(2018,2017)$ discuss the arguments for an accretionary Sveconorwegian orogen and the contrasts with the Grenville orogen in detail.

This article is protected by copyright. All rights reserved. 
Based on the available data from the Grenville and Sveconorwegian provinces, contiguity and continuity of the SE Laurentian and SW Baltican margins after ca. $1.5 \mathrm{Ga}$ is very much in question. Laurentia-Baltica proximity can be inferred until ca. 1.25 Ga (Fig. 2A), consistent with most other interpretations, but we note that this inference is rather poorly constrained.

Li et al. (2008), in a 'consensus' Rodinia reconstruction, show significant $\mathrm{N}-\mathrm{S}$ separation between Baltica and Laurentia at 1100 and $1050 \mathrm{Ma}$ (Fig. 2B), further invalidating correlation between the Grenville and Sveconorwegian orogens, which were both well underway by that time. By $950 \mathrm{Ma}$, Baltica had drifted north and occupied a latitude similar to Laurentia (Fig. 2C), where it remained until at least 900 Ma. Importantly, however, the longitude is unconstrained, giving rise to many possible permutations, as illustrated in Fig. 2B, C. In an attempt to reduce the number of possible configurations, we discuss the ensuing Neoproterozoic evolution to see if it can place some constraints on the generally hypothesized proximity of the two continents. We consider three different scenarios: (1) proximal Baltica and Laurentia, more or less as traditionally envisaged; (2) Baltica and Laurentia in relative proximity, but with Baltica shifted eastward compared to scenario 1; and (3) significant separation of Baltica and Laurentia with no contiguous margin.

\section{Neoproterozoic tectonic evolution of the North Atlantic region}

Interpretation of the tectonic history of the North Atlantic region (Figs. 2, 3) was advanced with the concept of the Valhalla orogen (Cawood, et al., 2010). This orogenic system encompasses a series of accretionary events that compressed and inverted at least two supercycles of basin formation between ca. 1030 and $710 \mathrm{Ma}$. The remnants of this basin system are now metamorphosed and widely distributed in Early Paleozoic allochthonous units across the circum-North Atlantic region (Fig.

3). Cawood et al. (2010) interpreted the Valhalla orogen to represent an exterior, accretionary orogen along the northeastern margin of Laurentia, following $\sim 90^{\circ}$ clockwise rotation of Baltica (Fig. $2 A, B)$.

This article is protected by copyright. All rights reserved. 
Tomographic (Slagstad, et al., 2018) and geochronologic (Tucker, et al., 1990) data suggest that the Sveconorwegian orogenic belt continued northwards along the coast of W Norway, and ca. $1066 \mathrm{Ma}$ mafic dikes (Mertanen, et al., 1996) and ca. 1050 Ma extensional structures (Koehl, et al., 2018) in northern Norway may be an expression of tectonic activity outboard of the present-day margin. After ca. $1000 \mathrm{Ma}$, the Sveconorwegian orogen was dominated by widespread extension (Slagstad, Roberts, Coint, Høy, Sauer, Kirkland, Marker, Røhr, Henderson, Stormoen, Skår, Sørensen and Bybee, 2018, Viola, et al., 2011), with intermittent compression (Bolle, et al., 2018); thus both tectonic style and timing match that of earliest Valhalla orogenesis, consistent with different zircon $\mathrm{Hf}$ evolutionary pathways for the Grenville vs. Sveconorwegian/Valhalla orogens (Spencer, et al., 2018).

The last stage of extension in the Sveconorwegian orogen is recorded by mafic dikes at ca. $850 \mathrm{Ma}$ (Walderhaug, et al., 1999), and extensional structures in northern Norway as young as ca. $800 \mathrm{Ma}$ (Koehl, Bergh and Wemmer, 2018) suggest that the entire present-day coastline of Norway was affected by far-field tectonic forces (Fig. 2D). An extensional depositional environment with intervening compressional phases was active until at least ca. $590 \mathrm{Ma}$ (Cutts, et al., 2010, Kirkland, et al., 2016), covering large tracts of Baltica (Sparagmite Basin, Nystuen, 1987), Laurentia (Spencer, et al., 2015), exotic entities including the Pearya terrane (Estrada, et al., 2018, Malone, et al., 2017, Trettin, 1987), domains of northeastern Russia (Lorenz, et al., 2012), the Moine and Dalradian supergroups (Kirkland, et al., 2008, Strachan, et al., 2013), the Kalak Nappe Complex in northern Norway (Kirkland, et al., 2007), Krummedal succession on Greenland (Kalsbeek, et al., 2000), and terranes on Svalbard (Johansson, et al., 2005) (Fig. 2E). This series of linked basins received detrital input from the eroding Sveconorwegian orogen and other, older and younger continental sources. Sedimentation was interrupted by compressional orogenic events e.g., the Renlandian (980-910 Ma), Knoydartian (840-830 Ma) (Cawood, Strachan, Cutts, Kinny, Hand and Pisarevsky, 2010), and Snøfjord events (Kirkland, et al., 2006), probably related to intermittent active-margin advance, consistent with formation along a long-lived, active margin until at least ca. $700 \mathrm{Ma}$. These units are

This article is protected by copyright. All rights reserved. 
exclusively found in Early Paleozoic allochthons, and their relationship to their current basements is unknown.

\section{Discussion}

Scenario 1 is essentially the same as that suggested by Slagstad et al. (2017), where the Grenville and Sveconorwegian orogens reflect different settings along the same continental margin, akin to the Himalaya (collision) and Indonesian (arc) orogens on the southern Asian margin (Fig. 2D, G). The North Atlantic allochthons cannot be readily incorporated into this scenario, but since the relationship between the allochthons and their basement is essentially unconstrained, this does not rule out this scenario.

Recognizing the accretionary nature of the Sveconorwegian orogen and assuming a more easterly but relatively Laurentia-proximal location of Baltica at ca. 1.0 Ga, allows a second scenario, in which the Sveconorwegian orogen forms part of the early Valhalla orogenic system (Fig. 2E, H). As outlined above, this shift in paradigm permits an internally consistent interpretation that ties the main orogenic events of the North Atlantic region together into a coherent tectonic framework that is valid until ca. $700 \mathrm{Ma}$.

Late Meso- and early Neoproterozoic accretionary orogens are found on most continents (e.g., Campanha, et al., 2019, Cawood, et al., 2009) and although the allochthonous North Atlantic Neoproterozoic successions can be correlated based on similarities in stratigraphy, metamorphic and magmatic history, and provenance (e.g., Cawood, Strachan, Cutts, Kinny, Hand and Pisarevsky, 2010, Kirkland, Daly and Whitehouse, 2007, Strachan, Prave, Kirkland and Storey, 2013), it is likely that there were several other, coeval active margins with broadly similar tectonic and temporal evolution. Thus, unless the allochthons show some unique feature that allows them to be correlated, e.g., age of deposition, metamorphic and magmatic events, one could argue that they are not 
correlative (Fig. 2F, I; Corfu, et al., 2007). Complicating things even further is the fact that the Neoproterozoic successions were accreted onto their respective basements during Early Paleozoic orogenesis, and may even have been accreted onto one continent but now be stranded on the margin following subsequent break up. This cryptic tectonic evolution allows for a third and probably most controversial, but nonetheless possible, scenario in which Laurentia and Baltica separated at or before ca. 1.25 Ga and remained separate until Early Paleozoic Caledonian continent-continent collision.

\section{Conclusions}

Given our present knowledge about the tectonic evolution of the Grenville and Sveconorwegian orogens, the ensuing Neoproterozoic evolution of the North Atlantic region, and paleomagnetic constraints, a number of different Baltica-Laurentia configurations in Rodinia are possible. These include scenarios where the two continents remain in relative proximity during and after GrenvilleSveconorwegian orogenesis, forming different portions along the same active margin, analogous to the Himalayan-Indonesian portion of the southern Asian margin. Alternatively, a paleomagnetically unconstrained eastward shift of Baltica would allow the Sveconorwegian orogen to represent the early stages of the Valhalla orogen. This scenario accounts for the current distribution of Neoproterozoic successions in Early Paleozoic allochthons around the North Atlantic, but assumes that the allochthons formed in relative proximity to their currently local basement, for which there is no clear evidence. The third scenario is that Baltica and Laurentia separated at or before ca. $1.25 \mathrm{Ga}$ and remained separated until Early Paleozoic Caledonian continent-continent collision. In this scenario, the Neoproterozoic units resting on Baltica may be derived from the Valhalla orogen or unrelated but similar accretionary orogens elsewhere. The least likely scenario appears to be the "classic" configuration where the Grenville and Sveconorwegian provinces represent one side of an extensive collisional orogen formed during amalgamation of the Rodinia supercontinent. Such a scenario is at odds with (i) the available paleomagnetic data placing the two continents at

This article is protected by copyright. All rights reserved. 
significantly different latitudes during orogenesis, (ii) contrasting tectonic style and timing of the Grenville and Sveconorwegian orogens, and (iii) geological data from the Sveconorwegian orogen that appear inconsistent with continent-continent collision.

\section{Acknowledgements}

We thank Torkil Røhr and other colleagues for inspiring discussions, and our respective institutions for their support in earlier work that has led up to the interpretations presented herein. Fernando Corfu and Peter Cawood are thanked for constructive comments on an earlier version of the manuscript that resulted in significant clarification of this work.

\section{References}

Bingen, B., Mansfeld, J., Sigmond, E.M.O. and Stein, H.J., 2002. Baltica-Laurentia link during the Mesoproterozoic: 1.27 Ga development of continental basins in the Sveconorwegian Orogen, southern Norway Canadian Journal of Earth Sciences, 39, 1425-1440.

Bingen, B., Nordgulen, $\varnothing$. and Viola, G., 2008. A four-phase model for the Sveconorwegian orogeny, SW Scandinavia Norwegian Journal of Geology, 88, 43-72.

Bingen, B. and Viola, G., 2018. The early-Sveconorwegian orogeny in southern Norway: Tectonic model involving delamination of the sub-continental lithospheric mantle Precambrian Research, 313, 170-204.

Blereau, E., Johnson, T.E., Clark, C., et al., 2017. Reappraising the P-T evolution of the Rogaland-Vest Agder Sector, southwestern Norway Geoscience Frontiers, 8, 1-14.

Bolle, O., Diot, H., Auwera, J.V., et al., 2018. Pluton construction and deformation in the Sveconorwegian crust of SW Norway: Magnetic fabric and U-Pb geochronology of the Kleivan and Sjelset granitic complexes Precambrian Research, 305, 247-267.

Brewer, T.S., Åhäll, K.-I., Menuge, J.F., et al., 2004. Mesoproterozoic bimodal volcanism in SW Norway, evidence for recurring pre-Sveconorwegian continental margin tectonism Precambrian Research, 134, 249-273.

Bybee, G.M., Ashwal, L.D., Shirey, S.B., et al., 2014. Pyroxene megacrysts in Proterozoic anorthosites: Implications for tectonic setting, magma source and magmatic processes at the Moho Earth and Planetary Science Letters, 389, 74-85.

Campanha, G.A.C., Faleiros, F.M., Cawood, P.A., et al., 2019. The Tonian Embu Complex in the Ribeira Belt (Brazil): revision, depositional age and setting in Rodinia and West Gondwana Precambrian Research, 320, 31-45.

This article is protected by copyright. All rights reserved. 
Carr, S.D., Easton, R.M., Jamieson, R.A. and Culshaw, N.G., 2000. Geologic transect across the Grenville orogen of Ontario and New York Canadian Journal of Earth Sciences, 37, 193-216.

Cawood, P.A., Kröner, A., Collins, W.J., et al., 2009. Accretionary orogens through Earth history. In: Earth Accretionary Systems in Space and Time (P.A. Cawood and A. Kröner, eds). Geological Society of London, London.

Cawood, P.A., Strachan, R., Cutts, K., et al., 2010. Neoproterozoic orogeny along the margin of Rodinia: Valhalla orogen, North Atlantic Geology, 38, 99-102.

Coint, N., Slagstad, T., Roberts, N.M.W., et al., 2015. The Late Mesoproterozoic Sirdal Magmatic Belt, SW Norway: Relationships between magmatism and metamorphism and implications for Sveconorwegian orogenesis Precambrian Research, 265, 57-77.

Condie, K., 2013. Preservation and Recycling of Crust during Accretionary and Collisional Phases of Proterozoic Orogens: A Bumpy Road from Nuna to Rodinia Geosciences, 3, 240.

Corfu, F., Roberts, R.J., Torsvik, T.H., et al., 2007. Peri-Gondwanan elements in the Caledonian nappes of Finnmark, northern Norway: implications for the paleogeographic framework of the Scandinavian Caledonides American Journal of Science, 307, 434-458.

Culshaw, N.G., Jamieson, R.A., Ketchum, J.W.F., et al., 1997. Transect across the northwestern Grenville orogen, Georgian Bay, Ontario: Polystage convergence and extension in the lower orogenic crust Tectonics, 16, 966-982.

Culshaw, N.G., Slagstad, T., Raistrick, M. and Dostal, J., 2013. Geochemical, geochronological and isotopic constraints on the origin of members of the allochthonous Shawanaga and basal Parry Sound domains, Central Gneiss Belt, Grenville Province, Ontario Precambrian Research, 228, 131-150.

Cutts, K.A., Kinny, P.D., Strachan, R.A., et al., 2010. Three metamorphic events recorded in a single garnet: Integrated phase modelling, in situ LA-ICPMS and SIMS geochronology from the Moine Supergroup, NW Scotland Journal of Metamorphic Geology, 28, 249-267.

Dalziel, I.W.D., 1991. Pacific margins of Laurentia and East Antarctica as a conjugate rift pair: Evidence and implications for an Eocambrian supercontinent Geology, 19, 598-601.

Estrada, S., Mende, K., Gerdes, A., et al., 2018. Proterozoic to Cretaceous evolution of the western and central Pearya Terrane (Canadian High Arctic) Journal of Geodynamics, 120, 45-76.

Evans, D.A.D., 2009. The palaeomagnetically viable, long-lived and all-inclusive Rodinia supercontinent reconstruction. In: Ancient Orogens and Modern Analogues (J.B. Murphy, J.D. Keppie and A.J. Hynes, eds).

Evans, D.A.D., 2013. Reconstructing pre-Pangean supercontinents Geological Society of America Bulletin, 125, 1735-1751.

Gower, C.F., Ryan, A.B. and Rivers, T., 1990. Mid-Proterozoic Laurentia-Baltica: an overview of its geological evolution and a summary of the contributions made by this volume. In: MidProterozoic Laurentia-Baltica (C.F. Gower, T. Rivers and A.B. Ryan, eds). Geological Association of Canada, Special Paper.

Hoffmann, P.F., 1991. Did the break-out of Laurentia turn Gondwana inside-out? Science, 252, 14091412.

Johansson, Å., Gee, D.G., Larionov, A.N., et al., 2005. Grenvillian and Caledonian evolution of eastern Svalbard: a tale of two orogenies Terra Nova, 17, 317-325.

This article is protected by copyright. All rights reserved. 
Kalsbeek, F., Thrane, K., Nutman, A.P. and Jepsen, H.F., 2000. Late Mesoproterozoic to early Neoproterozoic history of the East Greenland Caledonides: Evidence for Grenvillian orogenesis? Journal of the Geological Society of London, 157, 1215-1225.

Karlstrom, K.E., Åhäll, K.-I., Harlan, S.S., et al., 2001. Long-lived (1.8-1.0 Ga) convergent orogen in southern Laurentia, its extensions to Australia and Baltica, and implications for refining Rodinia Precambrian Research, 111, 5-30.

Karlstrom, K.E., Harlan, S.S., Williams, M.L., et al., 1999. Refining Rodinia: geologic evidence for the Australian - western US connection in the Proterozoic GSA Today, 9, 1-7.

Kirkland, C.L., Daly, J.S. and Whitehouse, M.J., 2006. Granitic magmatism of Grenvillian and late Neoproterozoic age in Finnmark, Arctic Norway - Constraining pre-Scandian deformation in the Kalak Nappe Complex Precambrian Research, 145, 24-52.

Kirkland, C.L., Daly, J.S. and Whitehouse, M.J., 2007. Provenance and terrane evolution of the Kalak Nappe Complex, Norwegian Caledonides: Implications for Neoproterozoic Paleogeography and tectonics Journal of Geology, 115, 21-41.

Kirkland, C.L., Erickson, T.M., Johnson, T.E., et al., 2016. Discriminating prolonged, episodic or disturbed monazite age spectra: An example from the Kalak Nappe Complex, Arctic Norway Chemical Geology, 424, 96-110.

Kirkland, C.L., Strachan, R.A. and Prave, A.R., 2008. Detrital zircon signature of the Moine Supergroup, Scotland: Contrasts and comparisons with other Neoproterozoic successions within the circum-North Atlantic region Precambrian Research, 163, 332-350.

Koehl, J.-B.P., Bergh, S.G. and Wemmer, K., 2018. Neoproterozoic and post-Caledonian exhumation and shallow faulting in NW Finnmark from $\mathrm{K}-\mathrm{Ar}$ dating and $\mathrm{p} / \mathrm{T}$ analysis of fault rocks Solid Earth, 9, 923-951.

Li, Z.X., Bogdanova, S.V., Collins, A.S., et al., 2008. Assembly, configuration, and break-up history of Rodinia: A synthesis Precambrian Research, 160, 179-210.

Lorenz, H., Gee, D., Larionov, A.N. and Majka, J., 2012. The Grenville-Sveconorwegian orogen in the high Arctic Geological Magazine, 149, 875-891.

Malone, S.J., McClelland, W.C., von Gosen, W. and Piepjohn, K., 2017. The earliest Neoproterozoic magmatic record of the Pearya terrane, Canadian high Arctic: Implications for Caledonian terrane reconstructions Precambrian Research, 292, 323-349.

Mertanen, S., Pesonen, L.J. and Huhma, H., 1996. Palaeomagnetism and Sm-Nd ages of the Neoproterozoic diabase dykes in Laanila and Kautokeino, northern Fennoscandia Geological Society, London, Special Publications, 112, 331-358.

Möller, C., Andersson, J., Dyck, B. and Antal Lundin, I., 2015. Exhumation of an eclogite terrane as a hot migmatitic nappe, Sveconorwegian orogen Lithos, 226, 147-168.

Möller, C., Bingen, B., Andersson, J., et al., 2013. A non-collisional, accretionary Sveconorwegian orogen - Comment Terra Nova, 25, 165-168.

Moores, E.M., 1991. Southwest U.S.-East Antarctic (SWEAT) connection: A hypothesis Geology, 19, 425-428.

Nance, R.D., Murphy, J.B. and Santosh, M., 2014. The supercontinent cycle: A retrospective essay Gondwana Research, 25, 4-29.

Nystuen, J.P., 1987. Synthesis of the tectonic and sedimentological evolution of the late Proterozoic early Cambrian Hedmark Basin, the Caledonian Thrust Belt, southern Norway Norsk Geologisk Tidsskrift, 67, 395-418.

This article is protected by copyright. All rights reserved. 
Pisarevsky, S.A., Wingate, M.T.D., Powell, C.M., et al., 2003. Models of Rodinia assembly and fragmentation Geological Society, London, Special Publications, 206, 35-55.

Rivers, T., 2012. Upper-crustal orogenic lid and mid-crustal core complexes: signature of a collapsed orogenic plateau in the hinterland of the Grenville Province Canadian Journal of Earth Sciences, 49, 1-42.

Rivers, T., 2015. Tectonic setting and evolution of the Grenville Orogen: an assessment of progress over the last 40 years Geoscience Canada, $\mathbf{4 2}$.

Roberts, N.M.W. and Slagstad, T., 2015. Continental growth and reworking on the edge of the Columbia and Rodinia supercontinents; $1.86-0.9 \mathrm{Ga}$ accretionary orogeny in southwest Fennoscandia International Geology Review, 57, 1582-1606.

Slagstad, T., Maystrenko, Y., Maupin, V. and Gradmann, S., 2018. An extinct, Late Mesoproterozoic, Sveconorwegian mantle wedge beneath SW Fennoscandia, reflected in seismic tomography and assessed by thermal modelling Terra Nova, 30, 72-77.

Slagstad, T., Roberts, N.M.W., Coint, N., et al., 2018. Magma-driven, high-grade metamorphism in the Sveconorwegian Province, SW Norway during the terminal stages of Fennoscandian Shield evolution Geosphere, 14, 861-882.

Slagstad, T., Roberts, N.M.W. and Kulakov, E., 2017. Linking orogenesis across a supercontinent; the Grenvillian and Sveconorwegian margins on Rodinia Gondwana Research, 44, 109-115.

Slagstad, T., Roberts, N.M.W., Marker, M., et al., 2013. A non-collisional, accretionary Sveconorwegian orogen Terra Nova, 25, 30-37.

Spencer, C.J., Cawood, P.A., Hawkesworth, C.J., et al., 2015. Generation and preservation of continental crust in the Grenville Orogeny Geoscience Frontiers, 6, 357-372.

Spencer, C.J., Kirkland, C.L., Prave, A.R., et al., 2018. Crustal reworking and orogenic styles inferred from zircon $\mathrm{Hf}$ isotopes: Proterozoic examples from the North Atlantic region Geoscience Frontiers.

Spencer, C.J., Roberts, N.M.W., Cawood, P.A., et al., 2014. Intermontane basins and bimodal volcanism at the onset of the Sveconorwegian Orogeny, southern Norway Precambrian Research, 252, 107-118.

Strachan, R.A., Prave, A.R., Kirkland, C.L. and Storey, C.D., 2013. U-Pb detrital zircon geochronology of the Dalradian Supergroup, Shetland Islands, Scotland: implications for regional correlations and Neoproterozoic-Palaeozoic basin development Journal of the Geological Society, 170, 905-916.

Trettin, H.P., 1987. Pearya: a composite terrane with Caledonian affinities in northern Ellesmere Island Canadian Journal of Earth Sciences, 24, 224-245.

Tucker, R.D., Krogh, T.E. and Råheim, A., 1990. Proterozoic evolution and age-province boundaries in the central part of the Western Gneiss Region, Norway: Results of U-Pb dating of accessory minerals from Trondheimsfjord to Geiranger. In: Mid-Proterozoic Laurentia-Baltica (C.F. Gower, T. Rivers and A.B. Ryan, eds).

Viola, G., Henderson, I.H.C., Bingen, B. and Hendriks, B.W.H., 2011. The Grenvillian-Sveconorwegian orogeny in Fennoscandia: Back-thrusting and extensional shearing along the "Mylonite Zone" Precambrian Research, 189, 368-388.

Walderhaug, H.J., Torsvik, T.H., Eide, E.A., et al., 1999. Geochronology and palaeomagnetism of the Hunnedalen dykes, SW Norway: implications for the Sveconorwegian apparent polar wander loop Earth and Planetary Science Letters, 169, 71-83.

This article is protected by copyright. All rights reserved. 
Weil, A.B., Van der Voo, R., Mac Niocaill, C. and Meert, J.G., 1998. The Proterozoic supercontinent Rodinia: Paleomagnetically derived reconstruction for 1100 to 800 Ma Earth and Planetary Science Letters, 154, 13-24.

Wingate, M.T.D., Pisarevsky, S.A. and Evans, D.A.D., 2002. Rodinia connections between Australia and Laurentia: no SWEAT, no AUSWUS? Terra Nova, 14, 121-128.

\section{Figures}

Figure 1. Examples of simplified Rodinia models at ca. $1 \mathrm{Ga}$, highlighting the positions of Baltica and Laurentia. Early Rodinia models (Dalziel, 1991, Hoffmann, 1991, Moores, 1991) suggested a connection between present-day Canada and Australia and southwest USA and East Antarctica, referred to as SWEAT. Baltica was reconstructed adjacent to either Greenland or Labrador. Later, Weil et al. (1998) presented a paleomagnetic synthesis that generally supported the SWEAT configuration (A). More recent Rodinia reconstructions have revised the SWEAT configuration, proposing a configuration in which Australia was connected with western USA instead of Canada referred to as the AUSWUS configuration (Karlstrom, et al., 1999). Later, Wingate et al. (2002) and Pisarevsky et al. (2003) questioned the robustness of the previous models on the basis of new paleomagnetic data and proposed the AUSMEX configuration, with Australia adjacent to the southernmost part of Laurentia (B). Li et al. (2008) proposed yet an alternative configuration, somewhat similar to the SWEAT models (C, D). The most radical suggestion is perhaps Evans's (2009) model, who placed Amazonia at the northern margin of Rodinia, leaving the southern GrenvilleSveconorwegian margin facing a major ocean (E). Despite the differences between the models, the Grenville-Sveconorwegian correlation has rarely been questioned.

Figure 2. (A) 'Classic' pre-Grenvillian, Mesoproterozoic reconstruction of Baltica and Laurentia, with an extensive, active southern margin. Modified after Karlstrom et al. (2001). (B, C) Various BalticaLaurentia configurations permitted by the paleomagnetic data at ca. 1050 and 950 Ma. Latitudes are after Li et al. (2008) and various longitudes have been selected to illustrate various possible 
scenarios, including scenario 1 , which is the 'classic' contiguous Baltica-Laurentia configuration (D, G); scenario 2, with Baltica shifted eastward from its classic position $(E, H)$; and scenario 3, with Baltica and Laurentia separated and unrelated to each other. Given a range of geological arguments that the Sveconorwegian orogen did not form as a result of continent-continent collision, and the paleomagnetic data suggesting significant separation of Baltica and Laurentia at the peak of orogenic activity, the 'classic' configuration, with Baltica and Laurentia representing one side of a major collisional orogenic belt interior to Rodinia, seems the least likely. Abbreviations: BDD-BlekingeDalarne mafic dikes; GO-Grenville orogen; KAU-Kautokeino mafic dikes; M-Moine succession; PPearya terrane; SNO-Sveconorwegian orogen; SSv-Sørøy-Sværholt succession; Sv-Svalbard terranes.

Figure 3. North Atlantic region with relevant geologic features. Pink blocks correspond to late Mesoto early Neoproterozoic orogens, green to the late Neoproterozoic Timanian orogen, and dark blue to the Paleozoic Caledonian-Appalachian orogen. Red stars indicate areas where evidence of late Meso- through late Neoproterozoic deposition, deformation, and magmatism, interpreted to be related to active-margin processes in a long-lived Rodinia-exterior orogen, have been found in Caledonian allochthonous nappes. Yellow stars indicate similar evidence in autochthonous - with respect to Caledonian tectonism - positions. Abbreviations: ALN-Alnö carbonatite; D-Dalradian succession; EG-Egersund mafic dikes; Ext.-Extensional faulting; FEN-Fen carbonatite; HUNHunnedalen mafic dikes; KAU-Kautekeino mafic dikes; K-Krummedal succession; M-Moine succession; RB-Rockall Bank; SAR-Sarfartoq carbonatite; SIL-Sept Isles layered intrusion; SSs-Sørøy and Sværholt successions; Sv-Svalbard terranes.

This article is protected by copyright. All rights reserved. 


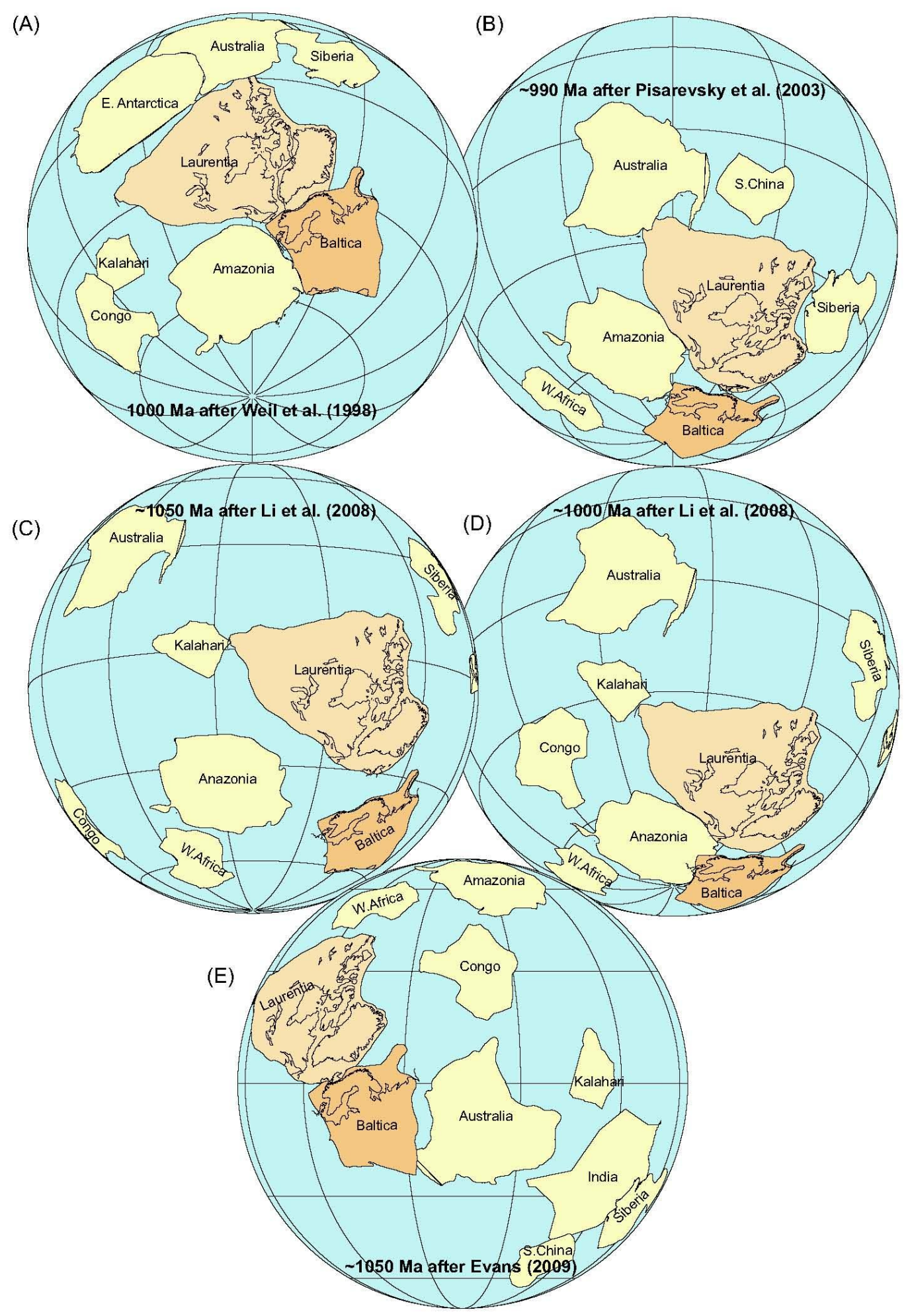

This article is protected by copyright. All rights reserved. 

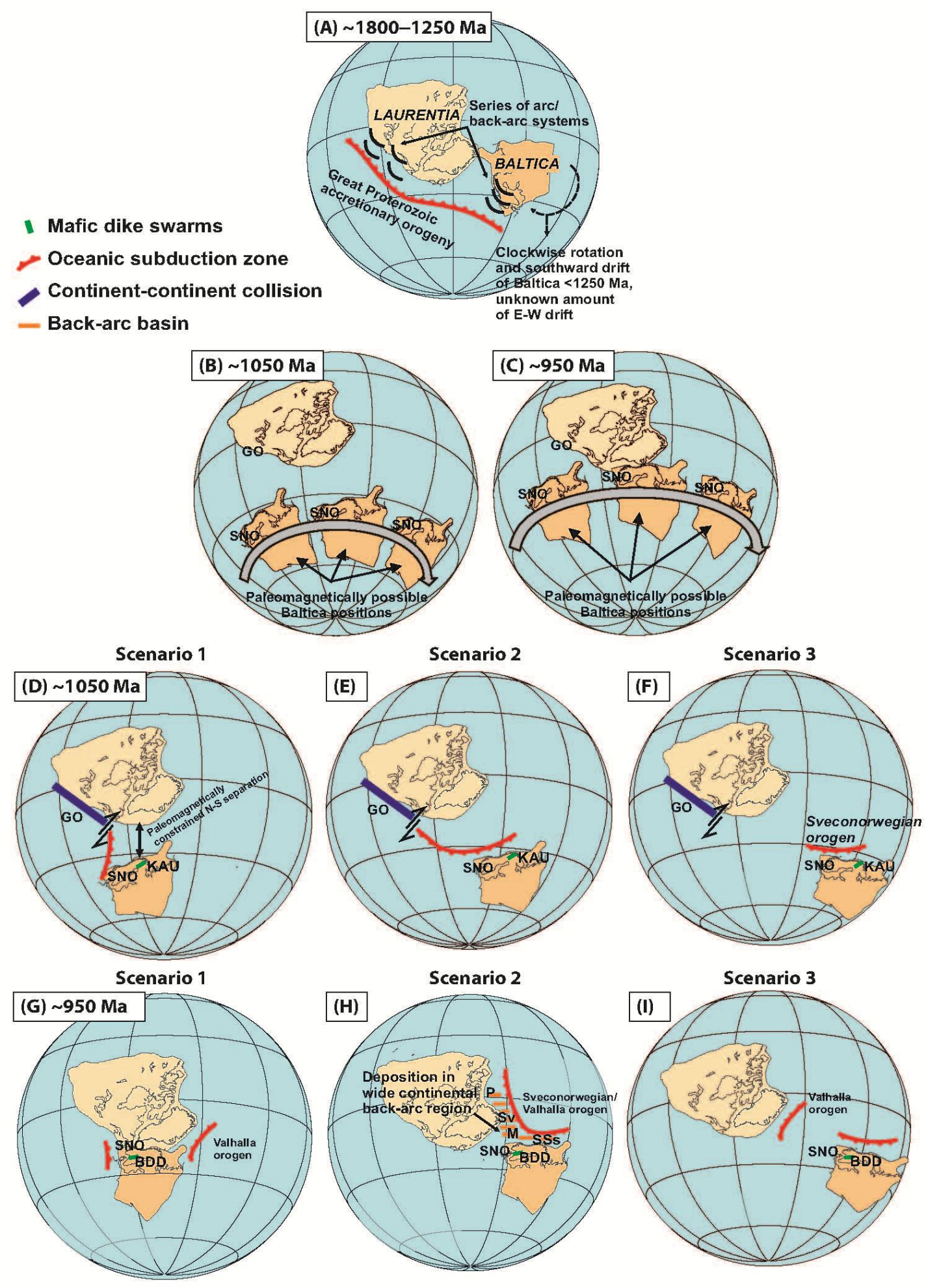

This article is protected by copyright. All rights reserved. 


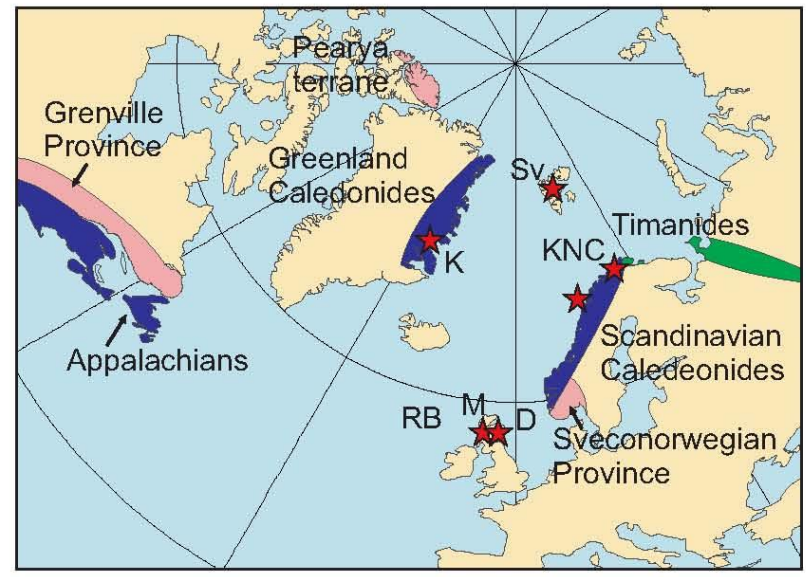

This article is protected by copyright. All rights reserved. 